\title{
REVOLUTION IN MILITARY AFFAIRS, MISSILE DEFENCE AND WEAPONS IN SPACE: THE US STRATEGIC TRIAD
}

\author{
Joelien Pretorius, University of Cambridge \\ and Research Fellow, Centre for International Political \\ Studies, University of Pretoria ${ }^{a}$
}

\begin{abstract}
American plans for Missile Defence (MD) and the weaponisation of space should be analysed in the larger framework of the contemporary Revolution in Military Affairs (RMA). ${ }^{1}$ Soviet military analysts have written about this revolution from as early as the 1970s, but it was the application of information age technology (IT) in the 1991 Gulf War that captured the imagination of military planners and policy makers, especially in the US. The US is actively pursuing an RMA, conceptualised as integrating new IT into weapons systems and integrated command, control, computers, intelligence, surveillance and reconnaissance (C4ISR) and, in turn, doctrinal, operational and organisational change in the military to take advantage of information dominance on the battlefield. This relates to MD and the weaponisation of space in two ways. Firstly, very few countries have the financial and technological capability to modernise their defence forces along the lines of a US-defined RMA, which means that they may resort to so-called asymmetric means to exploit the vulnerabilities or weaknesses of a strong, conventional power. Ballistic missiles (in association with chemical, biological or nuclear payloads) are one of the asymmetrical threats most commonly cited in speeches and military documents of the US and used as justification of MD. Secondly, the RMA increases the US military's reliance on space-based military assets for C4ISR. Placing weapons in space to protect these assets is seen as a logical step to ensure a key aspect of US dominance on the battlefield. This paper
\end{abstract}

\footnotetext{
${ }^{a}$ The author would like to express her sincere thanks to Prof Bruce Larkin and Peter Wright for 'musings' on earlier drafts of this article, the Pugwash Conferences on Science and World Affairs for providing a forum where earlier drafts were presented, the reviewers and Editor of Scientia Militaria for very useful comments and to the Commonwealth Scholarship Commission (CSC) for the funding of my graduate research on which this article is partially based. The views expressed are the author's and not attributable to the CSC.
} 
explores the extent to which the strategic framework of the RMA has a bearing on US MD and space weaponisation arguments.

\section{Introduction}

Strategy is what connects military power to political purpose; it is neither military power as such nor political purpose. Strategy is the use of force and threat of force for the ends of policy or as Clausewitz had it "the use of engagements for the object of the war." 2 A strategic framework therefore sets out a plan of action to achieve stated goals. In the case of the US the RMA is key to this plan of action. Some of the goals to be reached through the RMA can be traced as far back as World War II, while others are a response to the post-Cold War security environment as manifested most explicitly by the September 11 attacks on the US. The strategic framework as it is pursued today can also not be seen separately from the current US administration and the neo-conservatives' control of the security agenda. This paper sets out to frame US plans for MD and the arguments for the weaponisation of space within the discourse of the RMA as the strategic framework within which the US is trying to reach its defence goals. As such the article is essentially confined to an analysis of US strategic conceptions. ${ }^{3}$

\section{US defence goals and the RMA}

In order to understand the RMA as a plan of action it is important to understand the defence goals of the US and from there infer the reasons why the RMA is seen as the preferred plan of action to reach these goals. This section will discuss these goals within the context of three factors: the need for precision strike, the post-Cold War context and 'neo-conservatism'.

\section{The need for precision strike}

During both world wars the human carnage as a result of imprecise bombing was appalling. In order to hit a target, hundreds of bombs were dropped as close as possible to the target. During its involvement in World War II the US initially favoured a strategy of precision bombing but the lack of technology meant that they had to bomb in daylight, which resulted in planes and men lost to the enemy. Later the US chose the strategy of area bombing, most notably the fire-bombings of Japanese cities. As the international norm against indiscriminate attack grew the US engaged technology to develop precise strike capabilities without putting US Air 
Force (USAF) aircraft at risk. More humane warfare, it is argued, underlies the current strategic framework. The so-called CNN effect, i.e. the ability of news media to cover wars and broadcast images almost globally, enhances the prominence of this goal in the light of public revulsion of civilian suffering during wars.

\section{The post-Cold War context}

The strategic environment that characterised the Cold War era and informed military doctrine (doctrine can be defined as 'codified precepts that govern military operations $^{, 4}$ ) was a bipolar configuration between two superpowers that relied on mutually assured destruction to deter one another and consequently to keep their animosity cold. The post-Cold War context is one of multipolarity. ${ }^{5}$ Moreover, the symmetry of military power between the superpowers has given way to asymmetry in two ways. Firstly, the US has overwhelming conventional military power. Secondly, weaker parties may wish to acquire asymmetric means (not least nuclear, chemical and biological (NCB) weapons) to defend against or challenge a conventionally stronger state. This is sometimes perceived by conventionally stronger states as a means for weaker parties to hold strong states to ransom. Asymmetric parties also include non-state actors, most notably terrorists. The terrorist threat, played out on September 11, created the confirmation/justification for these perceived threats. The US National Security Strategy Report (2002) puts the attacks in (US) perspective by saying that if terrorists could inflict such damage with resources that hardly amount to the cost of one tank, what more are they not capable of if they exploit technologies and acquire chemical, biological, nuclear and information weapons. Rogue states drawing on the financial and human resources of a state can do even more harm. ${ }^{6}$ Essential to this argument is the proliferation of missile technology that has been in excess of intelligence expectations as well as the ability of rogue states to develop NCB weapons programmes. ${ }^{7}$ The A.Q. Khan missile and NCB technology network served as confirmation of this perception. The proliferation of missile technology along with the September 11 attacks confirmed for the US that geographic location no longer precludes direct attack.

From a US security perspective, the multiplicity of actors (who are less identifiable and predictable) and the proliferation of technologies previously monopolised by major powers form important drivers of uncertainty in the post-Cold War context. This uncertainty questions the value of Cold War nuclear doctrine and the ability of nuclear weapons to deter NCB threats as well as conventional (and asymmetrical) challenges to US security (and that of 'friends and allies'). It begs a strategy that is more flexible to address the different contingencies that uncertainty from potential adversaries and their capabilities may require. ${ }^{8}$ 
In response to the post-Cold War context, the US identified the following defence goals: ${ }^{9}$

- $\quad$ To assure US allies and friends of 'US steadiness of purpose and ability to fulfil security commitments.' The implications of assurance as a military goal relates to horizontal non-proliferation of nuclear weapons as the US nuclear umbrella and MD may keep Japan and Taiwan from 'going nuclear' in the face of regional nuclear threats posed by countries such as China and North Korea. However, it may have a negative effect on vertical proliferation as China may wish to increase its nuclear missiles in the face of Taiwan being protected by MD. The goal of assurance also sends a clear message that US defence is not confined to the homeland, but takes on a global nature that also involves creating regional security balances to protect the interests of allies and friends.

- To dissuade future military competition. It is important to note that dissuasion is not only directed against NCB weapons acquisition by adversaries, but against military competition in general. The means of dissuasion is identified as research, experimentation, test and demonstration programmes. (The Quadrennial Defense Review Report of 2001 (QDR) does not mention of what, but in subsequent documentation it is clear that these programmes include conventional, nuclear and space weapons). Moreover, a culture in the military that embraces innovation and risk-taking is seen as essential to dissuasion. The Iraq War can be construed as having the intended effect of dissuading other nations to pose a challenge to US interests.

- $\quad$ To deter threats against US interests, allies and friends, i.e. to discourage aggression or any form of coercion of the US, their allies or friends. Also, to do this through 'forward deterrence' in peacetime by deploying forces forward in critical areas. There has been an expansion in these forward deployed forces, and the US is even expanding further into Africa. ${ }^{10}$

- $\quad$ To decisively defeat any adversary if deterrence fails. This military goal is as much offensive as it is defensive in that the QDR explains that the US must have the capability to 'impose its will' on an adversary and this could include regime change and/or occupying foreign territory.

On face value, these goals are not radically different from the Cold War era, but the means of achieving them are. Here defence documentation highlights new approaches, namely: 
The shift from a threat-based to a capabilities-based model for defence planning: In the Cold War the Soviet Union and its allies were the identified threat, and defence capabilities were designed to counter that threat. In the absence of certainty of which states and non-state actors may pose a threat to its security, the US is planning to defend against the probable capabilities with which an adversary might challenge the US. The emphasis is thus not on whom the adversary is, but all the conceivable ways in which the US and its allies might be challenged. This involves not only developing asymmetrical military capabilities in terms of US superiority, but also denying adversaries the possibility to develop asymmetric means with which to counter US superiority.

The shift from nuclear to conventional deterrence: The credibility of nuclear deterrence in the post-Cold War context is called into question, not least because terrorists are not linked to territory or a nation that can be threatened with massive retaliation in the same sense as state actors are. At most nuclear deterrence can be directed against states that support terrorism, but even then a nuclear response can not be justified, especially if these countries themselves do not have nuclear weapons and are not directly responsible for an attack. Nuclear deterrence doctrine is only useful to deter against 'direct' nuclear and conventional attack from another state actor. In this light, conventional deterrence seems more credible for the purposes of imposing the US's will on states (a much broader objective than merely defence against direct attack). The means of conventional deterrence are intelligence capabilities that would allow knowledge of adversaries' military intentions and programmes, precision attack capability of static, mobile and deeply buried targets and rapidly deployable forces that can be maintained in a hostile country. ${ }^{11}$ Whereas nuclear weapons deter by threatening mass destruction, conventional deterrence is on the level of fighting. ${ }^{12}$ This does not mean that the US will give up its nuclear arsenal. The Nuclear Posture Review notes that a new triad of nuclear, non-nuclear, and defensive capabilities should be sought. This may explain research into new nuclear weapons that might be used in 'conventional warfare', such as Robust Nuclear Earth Penetrators that would target deeply buried bunkers suspected as NCB weapons factories/arsenals or low yield nuclear weapons, so called mininukes that would approach the explosive yield of conventional bombs. ${ }^{13}$ These programmes confirm the move to conventional deterrence by even making nuclear weapons more 'useable' on the level of fighting. ${ }^{14}$

Prevention and pre-emption: To achieve military goals US policy has also shifted from retaliation to preventive attack. The extent of this shift only becomes clear when preventive attack as a means of offensive defence is juxtaposed against pre-emptive attack. A pre-emptive strike in the face of an imminent attack is justified in international law, but preventive attack is not. Although the US has 
called the War on Iraq pre-emption in the light of Iraqi (presumed, but never found) weapons of mass destruction, the threat of attack against the US or its allies was not imminent and therefore it could only be argued that the war was preventive.

\section{Neo-conservatism}

The policy goals and ways of achieving them, which determine the US strategic framework, cannot be seen separately from the neo-conservatives that have, since September 11, made inroads into the US security policy apparatus. The neoconservatives originated from the Democratic Party in the late 1960s during the Vietnam War when they broke with the liberal democrats, who were against the Vietnam War. ${ }^{15}$ During the Reagan presidency they influenced foreign and strategic policy by labelling the Soviet Union an 'Evil Empire' and supporting a military build-up intended to bankrupt the Soviet Union if the latter tried to keep up with the US. For them it was a question of winning the Cold War. It is also significant that it was during the Reagan presidency that the US last saw a space programme (Strategic Defence Initiative or 'Star Wars') comparable with what is currently on the table. Once George Bush (senior), a conservative realist, who believed in multilateralism, came into power, he dismissed neo-conservatism and during Clinton's presidency the same was true. But the 'neo-conservative agenda' has in recent times gained much ground in George W. Bush's presidency and this agenda is characterised by the following:

- Disdain for multilateral organisations (and treaties): This relates to a belief that states, that are hostile towards the US, will use these organisations to curtail US power or to build their own power under the protection of these organisations. ${ }^{16}$ The disdain for international organisations also results from the view that these organisations and treaties are ineffective when it comes to enforcing norms of non-proliferation and arms control. In this respect, North Korea, Iraq and Iran (the infamous axis of evil) are portrayed as examples of states that have been able to acquire weapons of mass destruction or covert programmes to build these weapons while signatories to the NPT. There seems to be increasing evidence that the disdain for multilateral organisations expands to NATO in that the NATO framework may be more of a liability for swift and flexible military action if and when the US wants to 'project force'. Although not explicitly negative towards NATO, the National Security Strategy Report emphasises a list of changes necessary to carry out missions under new (supposedly post-Cold War) circumstances. ${ }^{17}$ However, the emphasis on 'coalitions of the willing' in the same report and the way in which the US 
has sought support outside NATO for its operations in Afghanistan and Iraq suggests that America is moving beyond NATO confines to achieve military goals.

- US exceptionalism: The US should not have to give away an inch of its sovereignty. This also corresponds to a notion of 'wrongdoers' as opposed to 'wrongdoing' in American foreign policy. Israel as a US ally is, for example, not regarded in the same light as North Korea, despite the former's covert nuclear weapons programme.

- A Wilsonian quest to spread democracy: Wilson, when declaring war against Germany in World War I said that the US had no quarrel with the German people, but with their authoritarian leaders. He firmly believed that the world should be made safe for democracy even if it takes force to do so. Premised on democratic peace theory (i.e. the notion that democracies do not wage war with one another), by spreading democracy world peace will be expanded as well. The same themes are echoed by the Bush (II) Administration, especially, but not exclusively, with respect to Afghanistan and Iraq. Spreading democracy is entwined with spreading free enterprise and liberal economic values. The spread of democracy and free enterprise are seen as key elements of the promotion of human dignity.

- A distinctive moral element: This is seen as the US's moral responsibility to take on the role of liberating people from dictators. ${ }^{18}$ This element extends to state-building in weak states, not least because these states are fertile ground for terrorists.

The objectives as outlined above have both been informing as well as been informed by what is referred to as the current RMA.

\section{The Revolution in Military Affairs}

Based on the premise that the way in which wars are fought undergo from time to time 'discontinuous change' as new technology or organisational concepts are introduced to increase military dominance, the current revolution involves the incorporation of information technology into weapons systems, doctrine and organisation. States that exploit the RMA will have military advantage and therefore, in the context of the capability-based approach as highlighted above, US strategy documentation makes it clear that the US has to 
- $\quad$ exploit the RMA and as such extend US military superiority into the future;

- $\quad$ guard against the possibility of states hostile to the US exploiting militarytechnical developments and challenging US military superiority; and

- $\quad$ prevent states from acquiring asymmetric means to decrease the value of the RMA to the US (or the US should acquire defence systems that will render asymmetric means of other states strategically useless, most notably MD).

It is especially the latter two that relate to weapons in space and MD, but before turning to them it is important to outline how the US has conceptualised the RMA by looking at the characteristics thereof as it manifests in US military planning, doctrine and operations (most notably in recent warfare) ${ }^{19}$

Precision-guided munitions: In Operation Desert Storm (the Gulf War of 1991) nine percent of the bombing was precision-guided. In Operation Iraqi Freedom (the recent Iraq War), at the point when formal combat operations were declared over, this figure had increased to 70 percent. The use of radar (JSTARS Joint Surveillance and Targeting Radar System) and Geographical Positioning System (GPS) and inertial guidance systems (both used in JDAMS - Joint Direct Attack Munitions System) in precision attack has meant that the US military has the ability to bomb military targets with lethality and accuracy - even in difficult environments, such as cities.

In strategic terms precision attacks support the Sun Tzu principle of "disarming an adversary before battle". ${ }^{20}$ During the Iraq War it made possible the first phase of the war, i.e. decapitation (taking out the Iraqi leadership), as well as the second phase of 'Shock and Awe' ${ }^{21}$ where imposing 'rapid dominance' through inflicting 'overwhelming force' was intended to render large parts of the Iraqi forces impotent whether as a result of real damage or through psychological effect.

This does not necessarily mean more humane warfare. The Project for Defence Alternatives (PDA) reported that both the absolute number and the proportion of non-combatants among Iraqi casualties were higher in Operation Iraqi Freedom than in Operation Desert Storm. What stands out in both these wars is the low ratio of US and British fatalities to Iraqi ones (a ration of 70-90 to 1). The relatively low Anglo-American casualty rate aside, both of the wars had death tolls comparable to many strategically significant wars of the past 40 years and as such "do not stand out unambiguously as 'low casualty' wars.",22 
Network-centric warfare: The interconnection of dispersed commanders, sensors, weapons and troops through a robust information network is referred to as network-centric warfare. Participants in this network have the capacity to develop a shared and real-time awareness of the battlefield. Commands can also be passed more rapidly than by the adversary. ${ }^{23}$ This is said to lift the 'fog of war', often the cause of casualties by friendly fire.

The Afghan model: Part of the RMA is the increasing reliance on smaller, specialised forces as was done in the Afghan War. This is partly to prevent taking casualties and the resultant political cost of soldiers returning home in body bags. It involves Special Operations Forces identifying targets and directing air strikes as well as a common command-control-communications-computers-intelligencesurveillance-and-reconnaissance $(\mathrm{C} 4 \mathrm{ISR})^{24}$ grid linking these forces (networkcentric warfare). Information is thus relayed not only to command and control centres in the theatre, but also to headquarters (in the Afghan and Iraq Wars this meant headquarters in the US) and platforms outside of the theatre (in the area of responsibility), such as aircraft carriers. Unmanned Aerial Vehicles (UAVs) are used to collect intelligence and beam images of the battlefield through the integrated information grid for hours. Special forces were also used to train and equip local forces in Afghanistan. ${ }^{25}$

Information operations: An element of the RMA is the increased prominence of information operations, i.e. taking advantage of the power of information and information technology and integrating all aspects of information to enhance military operations. As such information operations have an offensive and defensive dimension. Offensively it includes denying the adversary the benefits of information through deception and incapacitation (for example the US's reported use of HPM (High-powered Microwave) bombs (or e-bombs) to disable Iraqi computer and communication systems) as well as psychological operations, electronic warfare and ensuring and enabling means to collect and process information that could result in military advantage. ${ }^{26}$ The emphasis is thus on information dominance in the battle space and this dominance is key to military victory. Defensive information operations may include ensuring information security and defence of critical infrastructure in homeland defence, because the everyday reliance of a country's health, water, electricity, and transport infrastructure on computers may make it vulnerable to cyber attack and potential disruption.

RMA is in essence the paradigm within which US military planners see military transformation occurring and the role of space in bringing about this transformation is explicit in US strategy documentation. 


\section{Space and the RMA}

Space is seen as "a critical strand of DNA for US military transformation."27 The link between space and the RMA is threefold:

Space enables the current RMA: It enables the preferred way of warfare for the US, through satellites that are used for imaging, communication and precision guidance. As such the US is increasingly dependent on space. This is a 'chosen', not a 'necessary' dependence, because the US pursues the RMA type of war fighting that centralises C4ISR capabilities. US space assets, it is argued, are vulnerable to attack both in space as well as ground stations through physical attack or interference through electronic jamming. The contingency of a low yield nuclear explosion above the earth's atmosphere to damage nearby satellites is also mentioned in the US Space Commission Report. ${ }^{28}$ In effect, by putting more eggs in the space C4ISR basket, the US military has created vulnerability. But, this is not to say that an attack on US military satellites would leave the US 'blind' in the battlefield or severely undermine its military superiority. The Space Commission's warning that a "Space Pearl Harbor" could occur was regarded as alarmist, not only because it overestimated other countries' ability to exploit US space vulnerabilities, but because there are many passive and active defences against such a scenario. ${ }^{29}$

Denying the RMA to other states through space control and counter-space operations: The belief that the RMA awards military superiority to those who exploit it means that the US is not only interested in securing its own space assets. It also aims to prevent potential adversaries from obtaining space assets that could help the latter exploit the RMA, at least to such an extent as to challenge US superiority. This is clearly what Peter Teets, Under-Secretary of the USAF is referring to when he notes that new capabilities should be pursued " ...in order to exploit our nation's advantages and protect our asymmetric vulnerabilities to sustain our strategic position in the world." ${ }^{30}$ US policy in this respect is to temporarily disable hostile satellites through jamming or interference. But the Space Commission Report also calls for the ability to destroy these satellites and to use live fire events in space to test anti-satellite capabilities. ${ }^{31}$ The call for space control is reinforced by a USAF document entitled the 'Transformation Flight Plan', which asserts that: "it will require full spectrum, sea, air, land, and space-based offensive counterspace systems capable of preventing unauthorized use of friendly space services and negating adversarial space capabilities from low earth up to geosynchronous orbits. The focus, when practical, will be on denying adversaries access to space on a temporary and reversible basis." 32 When not practical, it can be assumed that preventive measures will be more permanent. This is an issue of particular concern to the US's 
European allies, who are developing the Galileo Global Positioning system with Chinese co-operation. Does US policy mean that Galileo may come under US attack should the US feel that it gives some RMA advantage to an adversary?

Space is the next phase of the RMA: The link between the RMA and space goes beyond that of an enabler. The Space Commission Report notes that space is not only useful from an RMA perspective in the sense of "passive collection of images or signals or a switchboard that can quickly pass information back and forth over long distances." 33 It is clear that weaponising space itself forms a part of the conceptualisation of the current RMA. The Space Commission Report makes an argument for the projection in, from and through space by noting the deterrent effect and in conflict, the extraordinary military advantage that this will provide. Weapons orbiting in space would reduce lengthy mobilisation periods, currently predicated on forward deployed bases, aircraft carriers and airlift capability to transfer weapons and soldiers to the battlefield. It would be the ultimate standoff and global strike weapon strategy. Space weapons used in an offensive mode could be the next phase of the RMA.

The Transformation Flight Plan notes that the USAF "is looking at ways to collect or generate large quantities of energy on orbit in order to rely on space-based platforms for more missions and provide a greater degree of true global presence. This would change many equations about traditional ideas of rapid response."34 The document goes on to outline a series of space weapons programmes, the research and development of which are likely to commence within the next five years and deployment envisioned as soon as $2015 .^{35}$ This corresponds with US wargaming scenarios which presume that space will be weaponised by $2015 .^{36}$ Some of the programmes mentioned in the Transformation Flight Plan include the following: ${ }^{37}$

- Air-launched anti-satellite missiles: These missiles will provide the capability of intercepting satellites in low earth orbit.

- Evolutionary air and space global laser engagement (EAGLE) airship relay mirrors: Space-based mirrors will extend the range of airborne, space and ground-based lasers, projecting different laser powers and frequencies to disable targets through illumination to destruction.

- Ground-based laser: This laser will transmit laser beams through the atmosphere to Low-Earth Orbit satellites for defensive and offensive space control.

- Hypervelocity rod bundles (dubbed 'rods from God' in the media): These rods are foreseen to travel through space at hypervelocity speeds, but could in the future be launched to orbit earth and strike ground targets on earth from space. 
- $\quad$ Space-based radio frequency energy weapon: Planned for the longterm, this will be a constellation of satellites containing high-power radio-frequency transmitters that would disrupt, destroy or disable electronics and command and control systems.

These space weapons programmes are envisioned for the long-term, i.e. 2015 and beyond, and from what we know, are only on the drawing board and not yet in the development phase. However, they suggest that a massive initiative is underway. The fact that US military planners are flaunting these plans in such an aggressive manner may prompt other powers to develop space weapons of their own, which in turn would provide the justification for the US to pursue these weapons. Thus, it will effectively result in a self-fulfilling prophecy.

\section{Missile defence and the RMA}

MD relates to the RMA in two ways, namely:

The asymmetry paradigm: The notion that actors hostile to the US will develop asymmetric means to counter-balance overwhelming US conventional military power can be referred to as the asymmetry paradigm. ${ }^{38}$ State actors may develop non-military asymmetric means, such as diplomatic activities in international forums (as was the case in the build-up to the Iraq War in the UN Security Council when it became clear that a second resolution to sanction war was unlikely to be passed). However, it is the military, especially the non-conventional means (notably ballistic missiles with nuclear, chemical or biological warheads) that have been used to justify MD, especially because non-state actors may also acquire these weapons. ${ }^{39}$ In this sense MD supports the capability-based approach in that it caters for the contingency of any actor acquiring NCB weapons and missiles to deliver them without having to identify specific threats.

Under President Bill Clinton, MD in the first instance was seen as protection of US territory against ballistic missile attack (National Missile Defence) as well as forward deployed US forces (Theatre Missile Defence). In December 2002 President Bush announced deployment of MD as early as 2004 (a month before presidential elections) and he opted for a single architecture (which could eventually be a global MD shield). ${ }^{40}$ It thus became clear that US allies and friends would also be protected by the system. The 2004 deployment of MD now seems uncertain due to technical failure of several interception tests. In some of the successful tests, interceptors seem to have been guided to the warhead of the incoming missile. ${ }^{41}$ 
Conventional deterrence: MD corresponds with the shift in deterrence doctrine. It renders an adversary's ability to deter the US through (NCB) missile attack on its forces, homeland or friends/allies obsolete. In the absence of mutual assured destruction, the option of deterring (or imposing one's will on) an enemy with conventional attack is left opened. Moreover, it is also argued that MD could even dissuade adversaries from developing these threat capabilities in the first place if they knew that MD would render them useless. ${ }^{42}$

\section{Conclusion}

Within the context of current US defence goals there is a strategic connection between the RMA and weapons in space on the one hand, and the RMA and MD on the other. This connection does not preclude a three-way link of mutual dependencies. 'Thoroughgoing' RMA requires secure control of space, which in turn requires secure and effective MD. The RMA is so heavily dependent on spacebased assets that the many ways in which an enemy could disable key space-based reconnaissance and communications elements by a strike from the ground must be thoroughly suppressed.

On closer inspection, the military advantage of weaponising space is questionable. Some have likened space weapons to nuclear weapons, saying that their short-term military advantage will soon be replaced by long-term woes of proliferation. ${ }^{43}$ It has also been argued that the US will undermine its own military superiority by moving warfare from earth (where it currently has overwhelming dominance) into space where other nations may pose competition with relatively rudimentary technologies. The notion that the US will be able to achieve fullspectrum dominance through unilateral space weaponisation will only work if they can suppress strikes from earth pre-emptively. Not only are space technologies often dual-use, making it difficult to determine whether a civilian satellite is being launched as opposed to a space weapon, but pre-emptively shooting down or threatening other countries' space launches could be regarded as acts of war. Such a policy could seriously complicate the current tacit acceptance of US military superiority among the major powers of the world.

Proponents of space weaponisation in the US, most notably the current Secretary of Defence, Donald Rumsfeld, assert that the weaponisation of space is inevitable. Space, like land, sea and air, is just another medium of conflict that will inevitably see warfare and therefore demands that the US, as a forward-looking country, should be the first to exploit this inevitability. ${ }^{44}$ However, the argument that "history has predetermined weapons in space" seems to rest more on technological 
determinism, dressed up as the so-called capabilities-based approach. This approach asks only 'how' and 'with what' questions when it comes to warfare (and defence), while negating the 'who' and 'why' questions. The latter questions are essential to know the circumstances under which warfare takes place and to make the defence responses plausible and realistic. ${ }^{45}$

Planning for contingencies 'out of context' suggests that technology-related policy choices are not determined by rational cost-benefit analysis, but a drive towards perceived technological progress. The weaponisation of space seems to be driven by a largely Western worldview that equates technological efficiency in military affairs with military efficiency. The two are however, not synonymous as we have seen in the Iraq War. Despite the technological superiority of the coalition forces, they still have not won the war and it certainly has not been a less bloody war than other wars of the past 50 years, neither does it look like a more expedient war. ${ }^{46}$ A very narrow and technological interpretation of military efficiency is the only context in which the weaponisation of space makes sense. It is argued that US military superiority can be extended without weaponising space and unnecessarily compromising relations with other powers, most notably Russia and China. ${ }^{47}$ Space seems to be not the next military high ground, but the next technological high ground in military affairs.

As for MD, the US has been at lengths to reassure China and Russia that $\mathrm{MD}$ is directed at rogue states and terrorist threats. However, these countries are suspicious that US plans for MD may only be a cover for plans of weapons in space, especially in the light of the US's abstention in the UN General Assembly vote on the resolution to prevent an arms race in outer space (the resolution supports the PAROS initiative in the UN Conference on Disarmament). An initial response by China was to link their agreement to a moratorium and eventual convention on the production of fissile material (the Fissile Material Cut-Off Treaty) with negotiations on PAROS. ${ }^{48}$ This play between conventional military power and asymmetric means - by reserving the right to produce fissile material, China can increase its asymmetric means (nuclear deterrent) to counter US military superiority - is indicative of the negative impact of weaponisation of space on non-proliferation.

\section{Notes and references}

The concept (military) transformation has largely replaced the concept RMA in US vernacular, most notably as employed by Donald Rumsfeld in 'Transforming the Military', Foreign Affairs, 81(3), May/June (2002), pp.20-32. In American context there is, however, an argument to be made that the concepts essentially refer to the same types of changes in military affairs. Therefore, I will continue to use the concept RMA in this article with the understanding that it is interchangeable with that of military transformation as used by Rumsfeld. 
Colin Gray, Modern Strategy, (Oxford, 1999), p.17, 18.

Demarcating the scope of the paper in this way does not preclude reference to possible responses by other states or the hope that the paper will extract comparisons with the strategic frameworks of other states.

Leo MacKay quoted by Norman Davies, 'An Information-based Revolution in Military Affairs', In David Ronfeldt and John Arquilla (eds.), In Athena's Camp: Preparing for Conflict in the Information Age, (RAND, 1997), http://www.rand.org/publications/MR/MR880/ (accessed: 2005-02-10).

Some view 'unipolarity' in the context of US unilateralism and the assertion that the US is the only remaining superpower or hegemonic power (a la Robert Gilpin) with overwhelming military and economic dominance. However, to call the current international configuration 'unipolar' would be to negate the importance of regions (and regional powers), international organisations and transnational actors that characterise the international context.

National Security Strategy of the United States, 2002, www.whitehouse.gov/nsc/print/nssall.html (accessed: 2005-02-10).

US Quadrennial Defense Review Report, 2001,
www.defenselink.mil/pubs/qdr2001.pdf (accessed: 2005-02-12).

Nuclear Posture Review Report (2001), as leaked and posted on the web, http://www.globalsecurity.org/wmd/library/policy/dod/npr.htm (accessed: 2005-0212).

These goals are set out in the US Quadrennial Defense Review Report, 2001, www.defenselink.mil/pubs/qdr2001.pdf (accessed 2005-03-02), and subsequently reiterated in the Nuclear Posture Review Report (ibid), the National Security Strategy Report (op cit) and numerous speeches by President George W. Bush.

Eric Schmitt, 'Pentagon Seeking New Access Pacts for Africa Bases', New York Times, 5 July 2003.

Quadrennial Defense Review Report, op cit, p.12.

Lawrence Freedman notes that the combination of atom bombs and delivery means has meant in practice that war changed from a fight to a process of destruction and that RMA is the culmination of efforts of the past 25 years to reverse this tendency. Lawrence Freedman, 'The Revolution in Strategic Affairs', Adelphi Paper, no. 318 (1999), p.15.

This notion suggests a contradiction in terms. Conventional warfare ceases to be conventional when nuclear weapons are used. The new nuclear weapons would blur this traditional distinction. The concerns raised by such a lowering of the threshold of the use of nuclear weapons include the escalation to the use of high yield nuclear weapons, increased risk of proliferation of new nuclear weapons and the environmental and health risks of testing and using nuclear weapons in a 'conventional' way.

Although the US Congress did not approve the funding for the most contentious of these 'new nuclear weapons' programmes in FY 2005, this was largely a result of a budgetary process that is in disarray, rather than a rejection of the programmes as such. It is almost certain that President Bush will submit a funding request for these programmes in 2006 again. See Matt Martin, 'Congress Stops 2005 Funding for New US Nuclear Weapons', Washington Nuclear Update, BASIC, 24 November 2004, http://www.basicint.org/update/WNU041124.htm (accessed 2005-03-02).

Stephan Halper, Panel discussion on Neo-Conservatism, Cambridge University, June 2003. 
This approach is not unique to the Bush (II) Administration. However, the withdrawal from multilateral organisations and treaties and the notion of signing bilateral agreements with countries to exclude the US from the reach of multilateral organisations, such as the International Criminal Tribunal, have been more explicit since Bush's presidency. United States, The National Security Strategy Report, 2002, http://www.whitehouse.gov/nsc/nss.html (accessed: 2004-12-16). President Bush stated in his West Point Graduation speech: "We are in a conflict between good and evil. And America will call evil by its name. By confronting evil and lawless regimes we do not create a problem, we reveal a problem. And we will lead the world in opposing it", 1 June 2002, http://www.whitehouse.gov/news/releases/2002/06/20020601-3.html (accessed: 200502-11).

It is important to make clear that the current RMA is driven by the US's conception of the role of information in warfare. Other states have had marginal influence in determining the form of the current RMA (just as Germany's use of the tank led to blitzkrieg, which some analysts have referred to as one of the past RMAs). It is also important to note that there is nothing inevitable about military revolutions. Unless states recognise and exploit technologies or organisation concepts and adapt them to their goals and capabilities, there is no autonomous functional logic that brings about the RMA. It is thought that Sun Tzu was a Chinese general of about 500 B.C. Although there is some argument whether he indeed existed and was the author of 'The Art of War', this work, along with Clausewitz' 'On War', are still today the cornerstones of military strategy in most countries.

Harlan K. Ullman and James P. Wade, Shock and Awe: Achieving Rapid Dominance, (NDU Press Book, December 1996), http://www.iwar.org.uk/military/resources/shock-and-awe/shockindex.htm (accessed: 2005-02-10).

Carl Conetta, 'The Wages of War: Iraqi Combatant and Noncombatant Fatalities in the 2003 Conflict', Project on Defense Alternatives Research Monograph, \#8, 20 October 2003, http://www.comw.org/pda/0310rm8.html (accessed: 2005-02-11). IISS, op cit, p.18.

C4ISR is typical RMA jargon and suggests the network-centric approach. Command and control refers to the hierarchical communication between responsible officers and their subordinates in the battlefield, but it has increasingly become desirable to keep units in touch with one another across theatres of operation (communication) and this is now done digitally (computers) through intelligence (surveillance and reconnaissance) received from specialised systems (such as unmanned aerial vehicles). Ref: Lawrence Freedman (op cit), p.12. International Institute for Strategic Studies (IISS), Strategic Survey 2002/3, p.17, 18. Freedman, op cit, p.49.

Col. John Raymond, 'Transformation Communications: The Transatlantic Dimension', paper presented at RUSI Conference entitled "The Future of Transatlantic Military Space Relations", London, 11 October 2004. United States, Report of the Commission to Assess United States Nation Security Space Management and Organization, (January 2001). Michael O'Hanlon, Neither Star Wars nor Sanctuary: Constraining the Military Uses of Space, (Brookings Institute Press, 2004) p.21. 


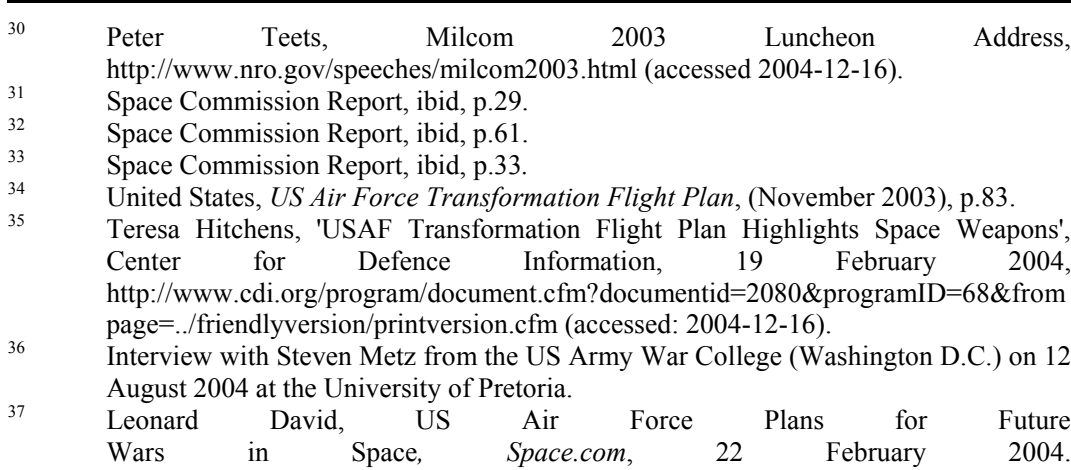
http://www.space.com/businesstechnology/technology/higher_ground_040222.html (accessed: 2004-12-02). Saïda Bédar, 'The Revolution in Military Affairs and the "Capability Race", Disarmament Forum, 4 (2001), p.27, 28.

For the purposes of this article I focus only on NCB missiles as a means of asymmetric warfare, but it should be emphasised that asymmetric warfare includes every other 'unexpected' military move, including insurgent actions, flying aircraft into buildings, information warfare, launching a satellite into space with gravel as payload so as to create destructive space debris, and so forth. IISS, op cit, p.29. Michael Evans, 'Star Wars Test Missile Was Guided by Beacon', Times of London, July 28, 2001, p.17.

$42 \quad$ IISS, op cit, p.29.

Karl Mueller, 'Totem and Taboo: Depolarizing the Space Weaponization Debate', RAND, 8 May 2002, p.9, http://www.gwu.edu/ spi/spaceforum/TotemandTabooGWUpaperRevised $\% 5 \mathrm{~B} 1 \% 5 \mathrm{D}$. pdf (accessed: 2004-12-16). Commission to Assess United States National Security Space Management and Organization Report, as quoted by Michael Krepon and Christopher Clary in Space Assurance or Space Dominance? The Case Against Weaponizing Space, http://www.stimson.org/pub.cfm?ID=81, (accessed: 2004-11-29). Freedman, op cit, p.59.

For those who see the glass as half full, the US has won the war, but not (yet) the peace. Michael Krepon and Christopher Clary, Space Assurance or Space Dominance? The Case Against Weaponizing Space, http://www.stimson.org/pub.cfm?ID=81, (accessed: 2004-11-29).

Nuclear Threat Initiative, Fissile Material Cut-off Treaty, http://www.nti.org/db/china/fmctorg.htm (accessed: 2005-02-11). 